\title{
Comparison of the fracture torque of different Brazilian mini-implants
}

\author{
Guilherme Machado Alvares de \\ Lima(a) \\ Mário Sérgio Soares ${ }^{(b)}$ \\ Sibele Sarti Penha ${ }^{(b)}$ \\ Marcelo Munhóes Romano(b)
}

(a) School of Dentistry, University of São Paulo, São Paulo, SP, Brazil.

(b) Department of Stomatology, Integrated Clinic, School of Dentistry, University of São Paulo, São Paulo, SP, Brazil.

\section{Corresponding author:}

Guilherme Machado Alvares de Lima

Av. Nossa Senhora da Assunção, 675, apto. 134E - Butantã

São Paulo - SP - Brazil

CEP: 05359-900

E-mail: guilhermelima01@gmail.com

Received for publication on Sep 13, 2010 Accepted for publication on Nov 22, 2010
Abstract: This study evaluated fracture torque by torsion, in relation to the length and diameter of orthodontic mini-implants, to demonstrate their viability for clinical and experimental use based on the torque recommended by the manufacturers. The fractures at the moment of insertion, whose incidence in the literature is around $4 \%$, are principally due to excessive force and the inability of the implant to resist rotational forces. Thirty orthodontic mini-implants of three commercial brands available in Brazil (Neodent $1.6 \times 9 \mathrm{~mm}$, Dentoflex $1.6 \times 9 \mathrm{~mm}$ and Kopp $1.6 \times 9 \mathrm{~mm}$ ) were attached to a device made specifically for this research, leaving the mini-implants with sufficient stability. The miniimplants were submitted to torsion torque, using a digital torque wrench, until their breaking point. The values obtained with the test were submitted to analysis of variance and the Tukey test. The mean values of mini-implant ruptures were $26 \mathrm{~N} . \mathrm{cm}$ for group A (Dentoflex), $25.4 \mathrm{~N}$. $\mathrm{cm}$ for group B (Kopp) and $32.8 \mathrm{~N} . \mathrm{cm}$ for group C (Neodent). From the Tukey test we could observe that the relationships between the means of the Dentoflex and Neodent groups, and between the Kopp and Neodent groups, were significant. Between the Dentoflex and Kopp groups, significance was nonexistent. All the values found in our research for fracture torque were higher than the limits recommended by the manufacturers for clinical use in orthodontics. The highest values were found in the Neodent group.

Descriptors: Dental Implantation; Torque; Orthodontics; Stress, Mechanical.

\section{Introduction}

The use of mini-implants for orthodontic anchoring in static mode is indicated in several situations, such as: anterior retraction, intrusion, verticalization, small orthodontic movements, among others. Therefore, the interaction between the implantodontist and the orthodontist is essential for planning. The shape of the mini-implant may be cylindrical or conical, and the active end may be self-drilling. Its installation is simple and quick, and it may be transmucosal or with flap under local infiltration anesthesia. The activation may be immediate or delayed, using typical orthodontic forces of 150 to 200 grams. ${ }^{1}$ The removal of implants may frequently be done without need of anesthesia, using removal torque in the opposite direction to its thread.

Past success rates, taking into account the numerous prototypes de- 
veloped, show success between $60-85 \% .^{2}$ Currently, this rate is around $90 \% .^{3}$ The general contra-indication for its use is the same for patients with restrictions against surgical interventions in general (systemic problems, patients too weak for surgery); with insufficient space and/or bone volume between the roots of the teeth; heavy smokers; patients with poor oral hygiene; pathologies of the oral mucosa; as well as unmotivated or uncooperative patients. ${ }^{4}$

Mini-implant fracture can occur due to several factors, such as: diameter, length, macrogeometry, surgical technique, implantation and removal torque, ${ }^{2,5,6,7}$ since the main concentration of stress is in the area of the neck of the mini-implant. ${ }^{5}$ Therefore, it is necessary to know the working system and its technical characteristics in order to avoid overtorquing. If a fracture occurs, removal of the fragment requires a surgical procedure. Depending on its location, preserving by taking clinical and radiographic controls of the fragment, or substituting the fractured mini-implant with another of larger diameter, or selecting a new point of implantation, are options that may be pursued.

Mini-implants may vary according to density, length and size of the transmucosal profile, and may have diameters between 1.0 and $2.0 \mathrm{~mm}$, lengths between 4 and $15 \mathrm{~mm}$, and transmucosal profiles measuring between 1 and $3 \mathrm{~mm} .{ }^{8}$ However, the clinical preference among orthodontists who use miniimplants, according to Brandão et al., falls on the shorter and less thick. The option for smaller screws decreases the risk of accidents during the surgical placement; but, it also brings possible technical disadvantages, such as less mechanical resistance by the device. ${ }^{7}$

In this way, as an experimental study, the maximum torques for torsion fracture in mini-implants from three different, commercially available Brazilian manufacturers, and their correlation with the manufacturers and recommended torque, were evaluated.

\section{Materials and methods}

Thirty orthodontic, self-drilling, titanium miniimplants, ASTM F-136 grade V, Ti-6Al-4V, commercially available from three different Brazilian companies, were used. Their assignment to the study groups is shown in Table 1 .

An aluminum fixture similar to a capsule was made to evaluate the torque necessary to cause a fracture. This had a channel, into which the mini-implant was inserted, to prevent lateral tension (Figure 1).

The mini-implants were positioned firmly into the fixture, leaving $1.5 \mathrm{~mm}$ of the screw, measured with a stainless-steel thickness gauge, ref. P.156 (Temper. Inox Instrumentos cirúrgicos e odontológicos Ltda., São Paulo, Brazil), not inserted into the aluminum capsule, since the thickness of the attached gingiva varies between 1 and $1.5 \mathrm{~mm} .^{9}$ Following, the capsule was screwed such that the mini-implant was stabilized, preventing rotational movement. The combined mini-implant/fixture was secured in a vise-grip (Mini vise $40 \mathrm{~mm}$ Western mod. F-40, E.I.C., New Delhi, India), leaving the head of the screw immovable. Next, the head of the mini-implant was placed into its specific insertion guide, according to its commercial brand. The

Table 1 - Characteristics and group assignment of the orthodontic mini-implants.

\begin{tabular}{l|l}
\hline Group A & $\begin{array}{l}\text { Ten Dentoflex mini-implants, } 1.6 \times 9 \mathrm{~mm} \text {, short-waist, } \\
0.2 \mathrm{~mm} \text { (Dentoflex Com. e Ind. de Mat. Odont. } \\
\text { Ltda., São Paulo, Brazil) }\end{array}$ \\
\hline Group B & $\begin{array}{l}\text { Ten Kopp mini-implants, } 1.6 \times 9 \mathrm{~mm} \text { (Kopp Produtos } \\
\text { Odontológicos, Curitiba, Brazil) }\end{array}$ \\
\hline Group C & $\begin{array}{l}\text { Ten Neodent mini-implants, } 1.6 \times 9 \mathrm{~mm}, \text { medium- } \\
\text { waist, (Neodent, Curitiba, Brazil) }\end{array}$ \\
\hline
\end{tabular}

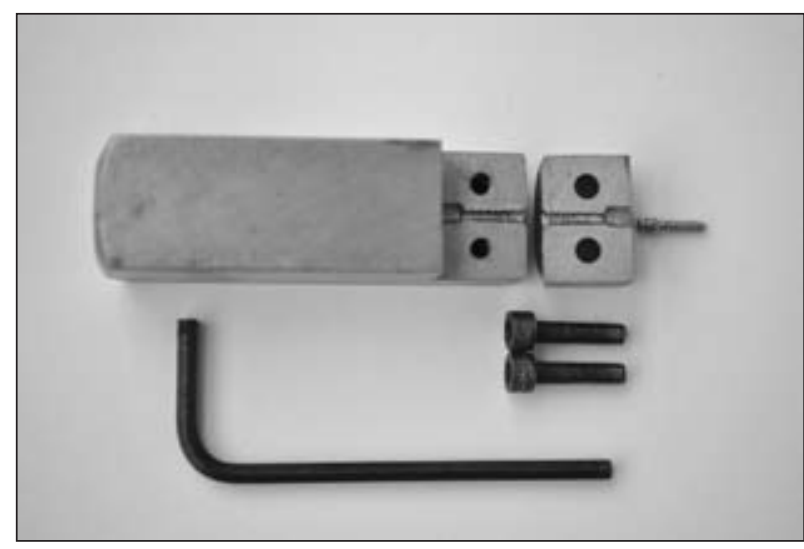

Figure 1 - The aluminum fixture. 
digital torque wrench TQ-680 (Instrutherm Ltda., São Paulo, Brazil), attached to the head of the miniimplant, measured the torque necessary to fracture it, noting the control of the installation torque according to manufacturer's instructions. The torque wrench was adjusted to the PEAK function, so we could know the maximum torque attained, and was reset to zero after being attached to the head of the mini-implant. The torque wrench was activated until the rupture torque was reached, thus representing the value obtained at the exact moment at which the fracture of the mini-implant occurred. This evaluation determines the resistance of the mini-implant to the torsion motion, by means of the maximum torque that can be applied to the specimen.

The maximum rupture torque was expressed according to the scale in N.cm.

Statistical analysis was done using the Biostat 5.0 software (Sociedade Civil Mamirauá, Belém, Brazil). ${ }^{10}$ The values obtained for the rupture torque were submitted to analysis of variance (ANOVA) and the Tukey test, in order to determine possible statistical differences between the groups. Descriptive statistical analyses, including mean, standard deviation, median, minimum and maximum values, were calculated for the three groups.

\section{Results}

The thirty fractured samples and the results, in N.cm, are shown in Table 2, numbered according to the sequence in which the tests were performed.

Table 2 - Fracture torque of the thirty samples tested (N.cm).

\begin{tabular}{c|c|c|c}
\hline Sample & $\begin{array}{c}\text { Group A: } \\
\text { Dentoflex }\end{array}$ & $\begin{array}{c}\text { Group B: } \\
\text { Kopp }\end{array}$ & $\begin{array}{c}\text { Group C: } \\
\text { Neodent }\end{array}$ \\
\hline 1 & 25 & 22 & 30 \\
\hline 2 & 26 & 24 & 33 \\
\hline 3 & 26 & 23 & 31 \\
\hline 4 & 26 & 24 & 34 \\
\hline 5 & 27 & 29 & 33 \\
\hline 6 & 26 & 26 & 34 \\
\hline 7 & 26 & 28 & 36 \\
\hline 8 & 25 & 23 & 34 \\
\hline 9 & 27 & 26 & 31 \\
\hline 10 & 26 & 29 & 32 \\
\hline
\end{tabular}

From the descriptive statistics shown in Table 3 , it is observed that the means of the groups were: 26 N.cm for group A (Dentoflex), 25.4 N.cm for group B (Kopp), and 32.8 N.cm for group C (Neodent).

Group B showed the greatest variance among the rupture torques, with 6.7111; and the least occurred in group A, with 0.4444 . The Coefficient of Variation shows the variance in percent, making the deviation more visual. Thus, among the rupture torques found, we observed that the greatest variation was observed for Kopp, with $10.20 \%$; followed by Neodent, with $5.53 \%$; and Dentoflex, with $2.56 \%$.

According to Table 4 (ANOVA), there were statistically significant differences for one criterion among both the Dentoflex and Neodent, and the Kopp and Neodent, groups. The highest values were for the Neodent group.

Table 3 - Descriptive statistics.

\begin{tabular}{l|c|c|c}
\hline & $\begin{array}{c}\text { Group A: } \\
\text { Dentoflex }\end{array}$ & $\begin{array}{c}\text { Group B: } \\
\text { Kopp }\end{array}$ & $\begin{array}{c}\text { Group C: } \\
\text { Neodent }\end{array}$ \\
\hline Sample size & 10 & 10 & 10 \\
\hline Minimum & 25 & 22 & 30 \\
\hline Maximum & 27 & 29 & 36 \\
\hline Arithmetic mean & 26 & 25.4 & 32.8 \\
\hline Variance & 0.4444 & 6.7111 & 3.2889 \\
\hline Standard deviation & 0.6667 & 2.5906 & 1.8135 \\
\hline Standard error & 0.2108 & 0.8192 & 0.5735 \\
\hline Coefficient of variation & $2.56 \%$ & $10.2 \%$ & $5.53 \%$ \\
\hline
\end{tabular}

Table 4 - ANOVA.

\begin{tabular}{l|c|c|c|c|c}
\hline $\begin{array}{l}\text { Sources of } \\
\text { variation }\end{array}$ & DF & SS & MS & $F$ & $p$ \\
\hline Treatments & 2 & 337.867 & 168.933 & \multirow{2}{*}{485.234} & $<0.0001$ \\
\hline Error & 27 & 94 & 3.481 & & \\
\hline
\end{tabular}

Table 5 - Tukey test.

\begin{tabular}{l|c|c|c}
\hline Group pairs & Difference & Test statistic & $p$ \\
\hline Dentoflex X Kopp & 0.6 & 1.0169 & NS \\
\hline Dentoflex X Neodent & 6.8 & 11.5246 & $<0.01$ \\
\hline Kopp X Neodent & 7.4 & 12.5415 & $<0.01$ \\
\hline
\end{tabular}




\section{Discussion}

Knowledge of the biomechanical performance of orthodontic mini-implants can provide less failure and better guidelines for clinical use, as they show the most varied shapes and dimensions.

The use of orthodontic mini-implants has some advantages in relation to other methods, such as: providing absolute anchoring; reduction of the risk of root injury; ease of handling, installation and removal; minimal irritation of adjacent tissues; controlled distribution of orthodontic mechanics; stability after installation. ${ }^{11}$ Among the disadvantages are trans-operative problems, including fractures at the moment of insertion (whose incidence in the literature is around $4 \%{ }^{5}$ ), due mainly to excessive force and the inability to resist rotational forces. ${ }^{12}$

To determine the mechanical resistance of any material, such as ductility, hardness and tenacity, mechanical tests that can evaluate their functional performance must be done. This is how the mini-implants used in this study were evaluated, in the state in which they are marketed. The insertion torque is proportional to the area of contact of the miniimplant with the bone. Thus, the larger the diameter, the greater the torque necessary, and this varies according to such characteristics as: external diameter, length and body of the mini-implants. Implants with a large cutting edge are easier to insert. ${ }^{13}$

A study conducted with the objective of determining the variability of the rotational forces applied to the prosthetic keys, for digital (with the fingers) use, aimed at tightening the implant components, pointed out average measurements of 26.58 N.cm ( \pm 6.52 percent)..$^{14}$ Fractures of the mini-implants may, thus, occur during digital insertion.

Self-drilling mini-implants have greater advantages than mini-implants that require surgical procedures that rely on the use of earlier surgical drills; however, the torque necessary to install the selfdrilling ones may bring forth other problems. ${ }^{15}$

Knowledge of the information relevant to the maximum torque tolerated by the screws should be made evident to dentists, in order to avoid operating failures; often, such information is not easily available in the packaging or leaflets. The businesses contacted stated that the maximum insertion torque for the mini-implants of $1.6 \mathrm{~mm}$ should be 20 N.cm for Neodent, 20 N.cm for Dentoflex, and 15 N.cm for Kopp.

The values found in this study exceeded the recommended values for maximum insertion torque (20 N.cm for Dentoflex and Neodent), and were much higher than the mean insertion force observed for mini-implants, which would be between 5 and 10 N.cm, and could reach 15 N.cm. ${ }^{15}$

We selected three Brazilian mini-implants, $1.6 \mathrm{~mm}$ in diameter. It is agreed that this diameter has a high success rate for primary stability. ${ }^{15,16}$ To avoid lateral movement, a metallurgical device was created to hold the mini-implants during the tests, such that there was no movement which would compromise the results obtained.

In Table 3, it is observed that the means of the groups were: $26 \mathrm{~N} . c \mathrm{~m}$ for group A (Dentoflex), 25.4 N.cm for group B (Kopp), and 32.8 N.cm for group C (Neodent). Thus, Group 1 (Dentoflex) presented very similar values (less variance between the rupture torques $=0.4444)$, while group $\mathrm{B}($ Kopp$)$ was discrepant within itself (greater variance among the rupture torques $=6.7111)$. The Coefficient of Variation indicates the variance in percent, making the deviation more visible. Thus, the group with the greatest variation in rupture torque was Kopp, with $10.20 \%$; followed by Neodent, with $5.53 \%$; and Dentoflex, with $2.56 \%$.

From the Tukey test we could observe that the relationship between the means of the Dentoflex and Neodent groups, and between the Kopp and Neodent groups, was significant. There was no significance between the Dentoflex and Kopp groups.

Although the three commercial brands of miniimplants evaluated were produced using the same type of material and following the same norms, some factors may interfere with the result. Possibly the best performance, by Group C (Neodent), may be explained by the presence of the transmucosal profile.

Pithon et al., ${ }^{17}$ performing a comparative study, analyzed the fracture torques of different brands of orthodontic mini-implants. They were inserted into a pig's femur with $1.7 \mathrm{~g} / \mathrm{cm}^{3}$ density (the values described for human mandibles are between 0.85 
and $\left.1.53 \mathrm{~g} / \mathrm{cm}^{3}\right)$. For Neodent implants of $1.6 \mathrm{~mm}$ x $7 \mathrm{~mm}$, a mean of $49.8 \mathrm{~N} . \mathrm{cm}$ and a minimum of 47.8 N.cm were observed. The other brands used in this study were SIN (mean of 99.5 N.cm), Titanium Fix (mean of 54.85 N.cm), and INP (mean of $54.3 \mathrm{~N} . \mathrm{cm}$ ). The values found in a similar test were less than the ones found by those researchers; one explanation for this may be the use of cortical bone by that group. ${ }^{17}$

Nova et al. ${ }^{18}$ showed no significant difference between SIN and Neodent mini-implants, with mean values of 35.14 N.cm for the SIN group and 27.42 N.cm for Neodent. The authors state that torques between 35 and 50 N.cm may cause fracture in the mini-implant, and recommend limiting the insertion torque to 20 N.cm. ${ }^{18}$ Given our results, there are evident differences between manufacturers and researchers.

Care must be taken when the cortical bone measures are greater than $2 \mathrm{~mm}$ because, depending on the different formats of the mini-implants,

\section{References}

1. Josgribert LFV, Henriques JFC, Henriques RP, Tirloni P, Kayatt FE, Godoy HT. A utilização dos mini-implantes na mecânica ortodôntica contemporânea. Rev Clin Ortod Dental Press. 2008 Ago-Set;7(4): 76-90.

2. Mah JBF. Temporary Anchorage devices: a status report. J Clin Orthod. 2005 Mar;39(3):132-6.

3. Park HS, Lee SK, Kwon OW. Group distal movement of teeth using microscrew implant anchorage. Angle Orthod. 2005 Jan-Jun;75(4):602-9.

4. Wuo AV, Horliana ACRT, Horliana RF, Soares MS, Tortamano A. Microimplantes ortodônticos: em que casos podem ser utilizados? Rev Assoc Paul Cir Dent. 2005;59(4):275.

5. Bucheter A, Wiechmann D, Koerdt S, Wiesmann HP, Pifko J, Meyer U. Load related implant reaction of mini-implants used for orthodontic anchorage. Clin Oral Implants Res. 2005 Ago;16(4):473-9.

6. Melsen B. Mini-implants: Where are we? J Clin Orthod. 2005 Sep;39(9):539-47.

7. Brandão FGT, Loureiro FL, Oliveira Junior HB, Carvalho PEG, Cotrim-Ferreira FA. Mini-implantes ortodônticos: quais os tamanhos mais vendidos? Rev Odontol UNICID. 2008 SetDez;20(3):254-60.

8. Coura GS, Andrade DS. Miniimplantes para ancoragem ortodôntica. Rev Clin Ortodon. 2007 Abr;6(2):98-104. the torque necessary for insertion varies from 20 to 40 N.cm. In these situations, it would be advisable to use pilot drills in order to decrease bone resistance, reducing the possibility of fracture. ${ }^{19}$

The excessive use of torque may result in fracture of the mini-implant and instability at the interface between the implant and the bone. Whenever possible, the insertion should be done using the torque wrench offered by the implant system to be used, and following the conditions suggested by the manufacturers.

Good surgical-orthodontic planning avoids the occurrence of occasional failures.

\section{Conclusion}

Within the limitations of this study, the fracture torque values found in our research are superior to those limits recommended by the manufacturers for clinical use in orthodontics. The highest values were found for the Neodent group.

9. Muller, HP, Schaller N, Eger T, Heinecke A. Thickness of masticatory mucosa. J Clin Periodontol. 2000;27(6):431-6.

10. Sociedade Civil Mamirauá. Bioestat 5.0: aplicações estatísticas nas áreas das ciências biológicas e médicas. Belém: Sociedade Civil Mamirauá; 2007.

11. Bae S, Park H, Kyung H, Kwon O, Sung J. Clinical application of micro-implant anchorage. J Clin Orthod. 2002 May;36(5):298-302.

12. Jardim FL, Utilização de mini-implantes na ortodontia. Rev Saude Pesqui. 2009 Jan;2(3):417-26.

13. Srinok V, Nisalak P, Verayangkura P, Charoenying H, Kyung $\mathrm{H}$. Association between insertion torque and the success of mini-screws used as orthodontic anchorage. Mahidol Dent J. 2008 Aug;28(2):202-214

14. Aziz, C. Avaliaçäo da variabilidade na aplicação de torque através de chaves digitais (com os dedos). Rev Bras Implant. 2001Jul-Set;7(3):18-20.

15. Miyawaki S, Koyama I, Inoue M, Mishima K, Sugahara T, Takano-Yamamoto T. Factors associated with the stability of titanium screws placed in the posterior region for orthodontic anchorage. Am J Orthod Dentofacial Orthop. 2003 Oct;124(4):373-8.

16. Motoyoshi M, Hirabayashi M, Miwa Uemura M, Shimizu $\mathrm{N}$. Recommended placement torque when tightening an 
orthodontic mini-implant. Clin Oral Implants Res. 2006 Feb;17(1):109-14.

17. Pithon M, Nojima L, Nojima N, Ruellas AC. Comparative study of fracture torque for orthodontic mini-implants of different trademarks .Oral Surg. 2008 May;1(2):84-7.

18. Nova MFP, Carvalho FR, Elias CN, Artese F. Avaliação dos torques para inserção,remoção e fratura de diferentes mini- implantes ortodônticos. Rev Dental Press Ortod Ortop Facial. 2008 Set-Out;13(5):76-87.

19. Song YY, Chab JY, Hwangc CJ. Mechanical characteristics of various orthodontic mini-screws in relation to artificial cortical bone thickness. Angle Orthod. 2007 Nov;77(6):979-85. 